ROCZNIKI HUMANISTYCZNE

Volume 67, issue 3- 2019

SELECTED PAPERS IN ENGLISH

DOI: http://dx.doi.org/10.18290/rh.2019.67.3-4en

REV. TADEUSZ GACIA

\title{
"EST LOCUS, AESTIFERO" (CARM. 1.18) AS AN EXAMPLE OF THE LOCUS AMOENUS TOPOS IN THE POETRY OF VENANTIUS FORTUNATUS
}

Descriptions of loci amoeni fill many a page in the literary oeuvre of Greek and Roman poets, and subsequently also in the works of the poets of Christian antiquity and the early Middle Ages. Even if in the latter they occur in the context of new ideas and representations, the way of thinking and the mode of artistic creation is still the same as with classical authors. This also refers to Venantius Fortunatus, the author of approximately 250 poetic works, the last poet of antiquity and a representative of the last phase of the ancient literary culture, who nevertheless spiritually belonged to the new epoch - the first bard of the Merovingians. ${ }^{1}$ One of the poems he wrote is "Est locus, aestifero." The incipit of the poem unambiguously locates it among the works in which the topos of locus amoenus is present. What indicates its presence is the phrase est locus, very often found in this type of poetry.

Rev. Tadeusz Gacia, PhD, Dsc, Assoc. Prof. (KUL) - Department of Latin Philology at the Institute of Literary Studies, the John Paul II Catholic University of Lublin (KUL); address for correspondence: ul. Jana Pawła II 7, 25-025 Kielce, Poland; e-mail address: tadeusz.gacia@kul.pl

The Polish version of the article was published in Roczniki Humanistyczne vol. 61, issue 3 (2013).

${ }^{1}$ Maria CytowsKa, "Ostatni poeta starożytności-Wenancjusz Fortunat," Meander 28, nos. 7-8 (1973): 307-320; Harald Hagendahl, Von Tertullian zu Cassiodor. Die profane literarische Tradition in dem lateinischen christlichen Schriftum (Studia Graeca et Latina Gothoburgensia, 44), Göteborg, 1983 - as cited in the Italian translation, in: Cristanesimo latino e cultura classica da Tertulliano a Cassiodoro, trans. D. Gianotti (Cultura Cristiana Antica. Studi; Rome, 1988), 188189. For information about Venantius Fortunatus, see: Leandro NAVARRA, "Venanzio Fortunato," in Nuovo dizionario patristico e di antichità cristiane, vol. 2 (Rome: Marietti, 2006), 3556-3558. 
A few years ago I devoted a short study to the presence of the locus amoenus topos in the Latin poetry of Christian antiquity, attempting to show it against the background of the classical tradition. ${ }^{2}$ It will not therefore be inappropriate if, for the convenience of the reader, who may not choose to become acquainted with that study right away, I summarize its main points here in a dozen or so sentences.

In Homer, descriptions of an idealized landscape that can be referred to as locus amoenus are incorporated into the contents of the narrative and blend in with the presented scenes. In Roman epic poetry, what corresponds the most to the Homeric descriptions of loci amoeni is the description of Elysium, which Aeneas enters in Book 6 of the Aeneid. In bucolics, both Theocritus' and Virgil's, locus amoenus is a significant element of the landscape populated by oxherds, goatherds, and shepherds living in close harmony with nature and love. There are also plenty of such descriptions in the Georgics, although there is no room there for the poetry and music of bucolic herdsmen. The perfect world-locus amoenus - is a reward for the effort of the farmer who lives in harmony with nature, and it is unimportant whether it is real or merely suggested by the author's ideas. Reminiscences of this kind - as an echo of the poet's personal nostalgia and a reflection of the poetic model of the epoch — can be found in Horace, in the epode titled "Beatus ille, qui procul negotiis," which is a praise of the idyllic life in the countryside. In the times of the Roman Empire and, later, in the Middle Ages, loci amoeni became an object of highly rhetoricized descriptions, isolated from the context. ${ }^{3}$ In the poetry of Christian antiquity, including its late period, locus amoenus is the biblical paradise, often depicted as Elysium. ${ }^{4}$ An original adaptation of this topos in that period-namely, its combination with biblical metaphors-is present in Victorinus' work, ${ }^{5}$ which has to be noted here because, consciously or not, Venantius Fortunatus would later be his imitator. In Victorinus, the topos of locus amoenus is incorporated as a basic trope-meaning the point of departure as well as in the functional sense-into the metaphor of the tree of life, with reference to Christ's cross.

\footnotetext{
${ }^{2}$ Tadeusz Gacia, "Topos locus amoenus w łacińskiej poezji chrześcijańskiego antyku," Vox Patrum 28, vol. 12 (2008): 187-198.

${ }^{3}$ Ernst Robert CURTIUS, Literatura europejska i tacińskie średniowiecze, trans. and ed. Andrzej Borowski (Cracow: Universitas, 1997²), 202-204.

${ }^{4}$ Prudentius, Cathemerinon, 3.101-105; Sedulius, Carmen paschale, 1.53-57; Avitus, Poematum de Mosaicae historiae gestis, 1.193-300; Dracontius, Laudes Dei, 3.751-753.

${ }^{5}$ Victorinus, De Pascha seu De Cruce, 61-63, 67-69.
} 
So much for references to the abovementioned article. It is, however, necessary to mention one other element that serves as a starting point for the present paper. Namely, there are certain characteristic phrases that poets typically use to begin their locus amoenus descriptions. In Virgil's bucolics, this phrase is huc ades. A herdsman often invites another one in this way, even if only to compete with him in a singing agon in describing the beauty of his own locus. ${ }^{6}$ Here, however, let us focus on the phrase est locus, which may constitute a kind of designator of a description marked by the presence of the topos I intend to discuss. This seems to be the case, above all, in rhetoricized poetry. Descriptions of loci amoeni are more schematic in it, and they are not naturally incorporated into the contents of the narrative as they used to be in epic poetry. This is the case in Lactantius' De ave Phoenice, a work that starts with the words "Est locus in primo oriente remotus," where the locus amoenus is the place in which Phoenix resides-Phoenix being a symbol of Christ in Christian authors' works, primarily of His resurrection, and a symbol of the saved man. ${ }^{7}$ In the previously mentioned Avitus, the description of the paradise where God settles the first parents begins as follows: "Est locus eoo mundi servatus in axe." ${ }^{\prime 8}$ The words "Est locus in terra diffundens quattuor amnes" begin the description of a locus amoenus included in Dracontius' narrative about the work of creation. ${ }^{9}$ The phrase est locus is present in Fortunatus' poem discussed here: "Est locus, aestifero."

The use of the locus amoenus topos is certainly not a particularly characteristic or dominant feature of Venantius Fortunatus' poetry. Yet, precisely for this reason, it is worth collecting and discussing various connotations of this kind, more or less clear, scattered over his works. It is also important because Fortunatus is a poet at the meeting of two epochs.

First, let us ask: What genre of poetry do the works containing the topoi of interest here represent? There is no simple answer to this question. This is because, when it comes to genre-related issues in general, Fortunatus' poetic

\footnotetext{
${ }^{6}$ By calling out huc ades, Corydon invites Alexis, a city-dweller, who scorns the rural shepherd because his master is in love with him; the description that follows shows all the charms of the rural world and has features typical of the topos under discussion (VIRGIL, Eclogues, 2.4555). The huc ades encouragement is uttered by Daphnis to Meliboeus (ibid., 7.9-11, 7.19-20). A huc ades call also opens the description of a locus amoenus, typical of a bucolic, in a fragment of Menalcas' pastoral song, sung by Moeris, in a different eclogue (ibid., 9.39-43).

${ }^{7}$ Lactantius, "De ave Phoenice," lines 1-30.

${ }^{8}$ Cf. Avitus, Poematum de Mosaicae historiae gestis, bk. 1, lines 193-300.

${ }^{9}$ Dracontius, "Laudes Dei," 1.174.
} 
oeuvre is highly heterogeneous. It comprises poetic letters, panegyrics, epithalamia, epitaphia, epicedia, epigrams, elaborate descriptive works, elegies, hymns, and works of other genres. The category that can be regarded as superior to all is its occasional character. Secondly, it is often very difficult to unambiguously specify what genre a given work should be classified under-and this is an even more characteristic feature. A work may, for example, be addressed to a particular person and have the form of a letter, conveying wishes of a long and auspicious life to the addressee; at the same time, its contents may be a descriptio - a description of a building, an object, or a place, and right next to it, in the same work, encomiastic elements may be present; in addition, the work may contain elements more characteristic of direct lyric poetry, with reference to the author's personal feelings. Thus, the composition of Fortunatus' works consists of a combination of several different, intertwining elements into a coherent whole. This combination of encomium and ekphrasis, cultivated in the literature ${ }^{10}$ of late antiquity has been highlighted - as a special characteristic of Fortunatus' poetry-by François Cassingena-Trévedy, who added that the poet also showed a visible tendency to create model descriptions of buildings, people, and scenes involving a transition from everyday reality to an ideal example. ${ }^{11}$

In ekphrastic works, the dominant element is description. The most frequently described objects are basilicas, churches, and other sacred buildings, liturgical utensils, and relics of saints. A smaller group of works is poems containing descriptions of secular buildings, estates, seasons, and nature, e.g. a garden or a river. Bearing in mind the combination of elements characteristic of different genres in one work, which has been emphasized above, I will now perform a review of poems in which the topos of locus amoenus is present.

The poem of interest here-"Est locus, aestifero" (Carm. 1.18)-is the first of those that should be mentioned. This is indicated by the incipit itself, with the characteristic phrase est locus. The next poem is the 19-line "Inter opima ferax" (Carm. 1.19), which provides a description of the town of Veriginis, located near Bordeaux. What encourages the reader to read on is the first distich, including the term amoenus:

\footnotetext{
${ }^{10}$ On the genres of Fortunata's poetry I wrote in my book 'Vernalia tempora mundo...' Wenancjusz Fortunat i jego poezje liryczne (Lublin: Jedność, 2014), 41-46.

${ }^{11}$ François CAssingena-TREvedy, "Son et lumière, la «matière » liturgique des Carmina de Venance Fortunat: entre l'adventus de la croix et l'icône de Martin de Tours," Camenae 11 (2012) (Présence et visages de Venance Fortunat XIVe centenaire): 1, as cited at http://www.parissorbonne.fr/IMG/pdf/6Cassingena_Camenae.pdf (accessed 21 June 2013).
} 
Inter opima ferax qua volvitur unda Garonnae,

Vereginis ripis vernat amoenus ager.

(lines 1-2)

The poem that follows, "Quamvis instet iter" (Carm. 1.20) has 24 lines and is a description of Bishop Leontius' estate, which the poet has visited. It will suffice here to quote a few of its lines:

\footnotetext{
Deliciis obsessus ager, viridantibus arvis, et naturalis gratia ruris inest.

Leniter adpulsus quotiens insibilat eurus, flexa supinatis fluctuat herba comis. Hinc alia de parte seges flavescit aristis pinguis et altricem palmes opacat humus.
}

(lines 7-8)

(lines 13-16)

A beautiful description, though perhaps with not particularly distinct elements of the presented topos, can be found in "Laus tibi forte minor" (Carm. 1.21) - a longer, 62-line poem; it is an ekphrasis of the river Gers (Egircius). Moving further, we come across a few other works, varying in length, addressed to Vilicus, Bishop of Metz. The first one of these- "Gurgite caeruleo pelagus" (Carm. 3.13) - is a poetic letter of 44 lines, describing the location of the city and containing numerous elements typical of the locus amoenus topos; it is also a praise of the addressee's pastoral zeal. Let us cite one of the distichs as an example:

$$
\begin{aligned}
& \text { Lambit odoriferas vernanti gramine ripas } \\
& \text { et lavat herbarum leniter unda comas. }
\end{aligned}
$$

$$
\text { (lines 3-4) }
$$

The allure of the countryside, described using the topos of locus amoenus, is the main motif of the 12-line poem "Sentio, summe Pater" (Carm. 5.7), written in hexameter. It is Fortunatus' reply sent to Felix, Bishop of Nantes, who invited him to his place in the country. In "Hic ver purpureum" (Carm. 6.6), a poem full of elements typical of locus amoenus descriptions, the poet depicts the beauty of the gardens founded by King Childebert. A description of an apple garden in the estate of Cantum is the content of the short poem "Venimus ad Cantum" (Carm. 6.7). The topos in question also appears in the panegyric work "Aestifer ignitas" (Carm. VII, 8), 
addressed to a man called Lupus. Nearly a half of this long poem (lines 132) is a very vivid presentation of a July day, with extreme heat oppressing animals and people, forcing them to seek shelter in some kind of locus amoenus, in the shade of trees, in a grove, in the grass by a rippling stream. Just like a person finds relief from scorching heat in a place like this, Fortunatus finds relief from his cares by recollecting Lupus.

Another group of works in which elements typical of the way of presenting locus amoenus can be found is poems addressed to Radegund. The life she chose, full of beauty and the fragrance of flowers growing in the convent's gardens, is depicted as an anticipation of vita beata-because the most perfect, unrivaled reflection of the earthly locus amoenus will be Paradise. The poet's favorite motifs, recurring in these poems, are images of violets, roses, and lilies growing in the garden at the convent or in the fields. This is the case in the following poems: "Tempora si solito" (Carm.8.6), "Frigoris hiberni" (Carm. 8.7), "O regina potens" (Carm. 8.8), and "Respice, delicias" (Carm. 11.11). The function of this kind of motif is best summarized in the words of the poem "O regina potens," in which the poet reminds Radegund that her destiny is eternal contemplation of the beauty of paradisal flowers: "Quamvis te exspectet paradisi gratia florum" (line 15) ${ }^{12}$. This is an innovative continuation of the use of metaphors known from Roman poetry. In Fortunatus, the characteristic element is a garden. It is a garden that becomes a perfect place epitomizing everything that was once dear to the Roman soul. As aptly observed by Anne Rolet, the author of a study titled "L'Arcadie chrétienne de Venance Fortunat. Un projet culturel, spirituel et social dans la Gaule mérovingienne," in Venantius Fortunatus the Roman garden becomes a place of perfect life and asceticism, understood as the practice of virtue, as well as a Christian metaphor of paradise-a Christian Arcadia. ${ }^{13}$

The third group of works in which the topos of locus amoenus is noticeably present is Fortunatus' hymns. Incidentally, thanks to several hymns (in essence, thanks to two or three) popularized by the liturgy of the Roman Church, Fortunatus found a permanent place in history, and Erich Auerbach, for instance, considers the Christian hymns to be his best works. ${ }^{14}$ I have two

\footnotetext{
${ }^{12}$ On this subject cf. GACIA, 'Vernalia tempora mundo...,' 159-165.

${ }^{13}$ Anne RoLET, "L'Arcadie chrétienne de Venance Fortunat. Un projet culturel, spirituel et social dans la Gaule mérovingienne," Médiévales 15, No 31 (1996): 109-127.

${ }^{14}$ Erich AUERBACH, Język literacki $i$ jego odbiorcy $w$ późnym antyku antyku tacińskim i średniowieczu, trans. Robert Urbański (Cracow: Homini, 2006), 235.
} 
works in mind here. The first one is "Crux benedicta nitet" (Carm. 2.1), ${ }^{15}$ a poem written in elegiac distich, in which the memory of the Cross is expressed, among other ways, by means of the locus amoenus topos. What also deserves attention is the presentation of the Cross as a living tree growing by life-giving water. In the four lines of the poem quoted below there are elements of this kind of imagery, though they overlap with reminiscences and biblical expressions, which are difficult to separate from one another:

\footnotetext{
Nullum uret aestus sub frondibus arboris huius, Luna nec in noctem, sol neque meridie.

Tu plantata micas, secus est ubi cursus aquarum, Spargis et ornatas, flore recente, comas.
}

(Carm. 2.1, lines 13-17)

The green color of the tree and its location by the water indicate that the Cross is a source of grace for believers and constantly bears new fruit. ${ }^{16}$

Elements characteristic of the presentation of locus amoenus are also scattered throughout the work titled "Tempora florigero" (Carm. 3.9). It is also written in elegiac distich, and because of its addressee-Bishop Felix of Nantes-as well as because of its subject matter, editors titled it "Ad Felicem episcopum de pascha,"17 since Fortunatus had composed it on the occasion of the baptism that Felix of Nantes administered at Easter to Saxons converted from paganism. The first part of the poem, consisting of $55 \mathrm{el}-$ egiac distichs (lines 1-38), is an ekphrasis of nature that awakens to life in spring and flourishes luxuriantly. The description of spring serves as the background for the feast of the Lord's Resurrection, celebrated at this time of year. ${ }^{18}$ It is worth citing a few expressions or longer passages filled with

\footnotetext{
${ }^{15}$ Cf. Venantius Fortunatus, "Crux benedicta nitet," trans. Krzysztof Bardski, in Muza tacińska. Antologia poezji wczesnochrześcijańskiej i średniowiecznej (III-XIV/XV w.), ed. Marek Starowieyski (Wrocław: Ossolineum, 2007), 160-161. Trans. T. Gacia, in Wenancjusz Fortunat, Poezje (Wybór), translated from Latin, preceded by an introduction and provided explanations by rev. Tadeusz Gacia (Lublin: TN KUL, 2018), 56-63.

${ }^{16}$ Cf. Magdalena Niewiadomska, "Wiersze o krzyżu Wenancjusza Fortunata. Próba interpretacji," Przeglad Tomistyczny 9 (2003): 281-310.

${ }^{17}$ Trans. A. Kowalkowski, Przeglad Klasyczny 1 (1935): 204. Reprinted in Muza chrześcijańska, vol. 2, Poezja tacińska starożytna i średniowieczna, trans. Zofia Abramowiczówna et al., introd., ed., and comp. Marek Starowieyski (Ojcowie Żywi 10; Cracow: Znak, 1992), 151-153; frag. 39-40, 31-38.

${ }^{18}$ In liturgy, the invocation Salve, festa dies (line 39) became the self-contained refrain of a paschal hymn, functioning in some measure independently of the whole "Tempora florigero." Different adaptations of the hymn resulted in new versions that could compete with the original, for example A. Kowalkowski's translation, in Muza łacińska, 161-163.
} 
phrases typical of the locus amoenus topos: "arbor amoena" (line 24) a tree); "Iam reparat viridans frondea tecta nemus" (line 22) and "undique fronde nemus" (line 34) — a green grove; "prata virent herbis [...]; subeunt stellantia lumina florum; floribus arrident gramina [...]" (lines 12-14) meadows, where green reigns supreme, flowers are budding, and plants are laughing.

Bearing the presented background in mind, we can now look at the poem "Est locus, aestifero." It is the $18^{\text {th }}$ work in Book 1 of Carmina, ${ }^{19}$ comprising 21 works, of which 20 are written in elegiac distich and the remaining one in iambic acatalectic. They are descriptions of church buildings erected or consecrated by bishops contemporary to Fortunatus. The last four poems in Book 1 are descriptions of towns or places that Fortunatus was personally familiar with. "Est locus, aestifero" (Carm. 1.18) consists of 18 lines and is a description of the country seat called Bissonum, near Bordeaux. As stated before, ekphrasis (and the topos of locus amoenus present here) is combined with a very clear motif of laudation-which, as we already know, constitutes a characteristic feature of Venantius Fortunatus' poetry.

De Bissonno, villa Burdigalensi (Carm. 1.18)

Est locus, aestifero quamvis sit tempore fervor, quo viret assidue flore refectus ager.

Respirant croceis depicta coloribus arva, flagrat odoriferis blandior herba comis.

Incola Bissonnum hunc de nomine prisco, milia septem urbs hinc burdigalensis abest.

Quo possessor amans praetoria grata locauit, partibus atque tribus porticus aequa subit.

Straverat ipsa solo senio rapiente, vetustas. Perdiderat vultum forma decora suum.

Haec meliore via, revocat labor ille Leonti, quo praesente domos nulla ruina premit.

Nunc quoque prosperius velut aula sepulta resurgit, et favet auctori vivificata suo.

Reddidit interea prisco nova balnea cultu quo recreant fessos blanda lavacra viros.

Hic referunt nutrisse lupos deserta tenentes. Intulit hic homines, expulit unde feras.

\footnotetext{
${ }^{19}$ Venantius Fortunatus, Poèmes, vol. 1: Livres I-IV, Texte établi et traduit par Marc Reydellet (Paris, 2002), 43-44.
} 


\section{ON BISSONUM, A COUNTRY-SEAT NEAR BORDEAUX}

There is a place where even in scorching heat Green fields of corn are always blossom-covered.

Saffron-colored patches send out fragrance, A most enjoyable smell flows from wild flowers and herbs. Local dwellers call this place by its ancient name-Bissonum. The city of Burdigala is seven miles away.

A happy owner once had a pleasing residence erected there And adorned with a magnificent portico on three sides.

But it crumbled with age and leaned to the ground; It had lost its former look of beauty and lustre.

Leontius is working hard to restore its glory.

The house won't crumble now that it is under his care.

Like a dilapidated palace, it is rising happily And joyfully applauding the one who has revived it.

He had baths built, too- as splendid as they used to be, Where a refreshing bath can restore your strength.

They say wolves could have made a living in this wilderness,

But he has brought people here, where wild beasts used to dwell. ${ }^{20}$

\section{BIBLIOGRAPHY}

\section{PRIMARY SOURCES}

Fortunatus, Venantius. Poèmes. 3 vols., edited and translated by Marc Reydellet. Paris: Ed. de Les Belles Lettres, 1994-2004.

\section{SECONDARY SOURCES}

AUERBACH, Erich. Język literacki i jego odbiorcy w późnym antyku tacińskim i średniowieczu [Literary language and its audience in late Latin antiquity and in the Middle Ages]. Translated by Robert Urbański. Cracow: Homini, 2006.

Cassingena-Trévedy, François. "Son et lumière, la «matière » liturgique des Carmina de Venance Fortunat: entre l'adventus de la croix et l'icône de Martin de Tours," Camenae 11 (2012) (Présence et visages de Venance Fortunat XIVe centenaire). http://www.parissorbonne.fr/IMG/pdf/6Cassingena_Camenae.pdf.

CURTIUS, Ernst Robert. Literatura europejska i tacińskie średniowiecze [European literature and the Latin Middle Ages]. Translated and edited by Andrzej Borowski. Cracow: Universitas, $1997^{2}$.

CYTowsKA, Maria. "Ostatni poeta starożytności-Wenancjusz Fortunatus” [The last poet of antiquity — Venantius Fortunatus]. Meander 28, no. 7-8 (1973): 307-320.

Fortunatus, Venantius. Poems, edited and translated by M. Roberts. Cambridge, MA 2017.

${ }^{20}$ Polish translation of this work is also featured in my Wenancjusz Fortunat, Poezje (Wybór), 42-43. 
GACiA, Tadeusz. "Motyw krzyża w twórczości Wenancjusza Fortunata na przykładzie Vexilla Regis" [The motif of the cross in the works of Venantius Fortunatus as exemplified by Vexilla Regis]. Roczniki Humanistyczne 46, no. 3 (1998): 101-112.

GACiA, Tadeusz. "Topos locus amoenus w łacińskiej poezji chrześcijańskiego antyku” [The topos of locus amoenus in the Latin poetry of Christian antiquity]. Vox Patrum 28, vol. 12 (2008): 187-198.

GaCiA, Tadeusz. Wenancjusz Fortunat. Poezje (Wybór). translated from Latin, preceded by an introduction and provided explanations by rev. Tadeusz Gacia. Lublin: TN KUL, 2018.

GaCiA, Tadeusz. 'Vernalia tempora mundo...' Wenancjusz Fortunat $i$ jego poezje liryczne. Lublin: Jedność, 2014.

NAVARRA, Leandro. "Venanzio Fortunato." In Nuovo dizionario patristico e di antichità cristiane, vol. 2, 3556-3558. Rome, Italy: Marietti, 2006.

Niewiadomska, Magdalena. "Wiersze o Krzyżu Wenancjusza Fortunata. Próba interpretacji” [Venantius Fortunatus' poems about the Cross: An attempt at interpretation]. Przeglad Tomistyczny 9 (2003): 281-310.

RolET, Anne. "L'Arcadie chrétienne de Venance Fortunat. Un projet culturel, spirituel et social dans la Gaule mérovingienne." Médiévales 15, No 31 (1996): 109-127.

\section{"EST LOCUS, AESTIFERO" (CARM. 1.18) \\ AS AN EXAMPLE OF THE LOCUS AMOENUS TOPOS \\ IN THE POETRY OF VENANTIUS FORTUNATUS}

\section{Summary}

In this article the author presents the poem "Est locus, aestifero," which appeared in the first book of Carmina, against the background of the topic of locus amoenus in the poetry of Venantius Fortunatus. The poem has 18 lines and is written in elegiac meter. It is a description of the village (country estate) of Bissonum, near Bordeaux. The ekphrasis, into which are woven the elements of the topic we are interested in, is combined with a very clear motif of laudation. This is a characteristic feature of Venantius Fortunatus' poetry. The English translation of the poem is an integral part of the essay.

Key words: Venantius Fortunatus; topos of locus amoenus; poetry.

Translated by Piotr Czyżewski

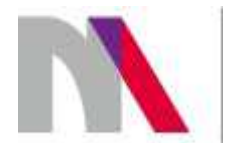

The preparation of the English version of Roczniki Humanistyczne and its publication in electronic databases was financed under contract no. 836/P-DUN/2018 from the resources of the Minister of Science and Higher Education for the popularization of science. 